\title{
Diet before and during Pregnancy and Offspring Health: The Importance of Animal Models and What Can Be Learned from Them
}

\author{
Pascale Chavatte-Palmer ${ }^{1,2, *}$, Anne Tarrade ${ }^{1,2}$ and Delphine Rousseau-Ralliard ${ }^{1,2}$ \\ 1 UMR BDR, INRA, ENVA, Université Paris Saclay, Jouy en Josas 78350, France; \\ anne.tarrade@jouy.inra.fr (A.T.); delphine.rousseau@jouy.inra.fr (D.R.-R.) \\ 2 PremUp foundation, Paris 75006, France \\ * Correspondence: pascale.chavatte@jouy.inra.fr; Tel.: +33-1-3465-2558 \\ Academic Editor: María M. Morales Suárez-Varela \\ Received: 11 March 2016; Accepted: 7 June 2016; Published: 14 June 2016
}

\begin{abstract}
This review article outlines epidemiologic studies that support the hypothesis that maternal environment (including early nutrition) plays a seminal role in determining the offspring's long-term health and metabolism, known as the concept of Developmental Origins of Health and Diseases $(\mathrm{DOHaD})$. In this context, current concerns are particularly focused on the increased incidence of obesity and diabetes, particularly in youth and women of child-bearing age. We summarize key similarities, differences and limitations of various animal models used to study fetal programming, with a particular focus on placentation, which is critical for translating animal findings to humans. This review will assist researchers and their scientific audience in recognizing the pros and cons of various rodent and non-rodent animal models used to understand mechanisms involved in fetal programming. Knowledge gained will lead to improved translation of proposed interventional therapies before they can be implemented in humans. Although rodents are essential for fundamental exploration of biological processes, other species such as rabbits and other domestic animals offer more tissue-specific physiological (rabbit placenta) or physical (ovine maternal and lamb birth weight) resemblances to humans. We highlight the important maternal, placental, and fetal/neonatal characteristics that contribute to developmentally programmed diseases, specifically in offspring that were affected in utero by undernutrition, overnutrition or maternal diabetes. Selected interventions aimed at prevention are summarized with a specific focus on the 1000 days initiative in humans, and maternal exercise or modification of the $n-3 / n-6$ polyunsaturated fatty acid (PUFA) balance in the diet, which are currently being successfully tested in animal models to correct or reduce adverse prenatal programming. Animal models are essential to understand mechanisms involved in fetal programming and in order to propose interventional therapies before they can be implemented in humans. Non-rodent animals are particularly important and should not be neglected, as they are often more physiologically-appropriate models to mimic the human situation.
\end{abstract}

Keywords: DOHaD; fetal programming; rodent and non-rodent animal models; 1000 days

\section{Developmental Origins of Health and Diseases}

Although earlier works suggested that developmental conditions during pregnancy were likely to impact postnatal development up to adulthood, Barker and colleagues' epidemiological studies were the first to clearly demonstrate the association between low birth weight, used as a proxy for impaired fetal nutrition, and increased risks of non-communicable diseases such as diabetes and hypertension [1,2]. "Fetal programming", now currently referred to as the Developmental Origins of Health and Disease (DOHaD), was subsequently demonstrated to be the consequence of environmentally-induced perturbations during development, affecting not only those small for 
gestational age but also those large for gestational age infants. The prevalence of metabolic disorders has increased considerably in recent years worldwide. Regardless of whether or not lifestyle choices and habits during the autonomic life contribute clearly to these epidemics, there is growing evidence suggesting that the maternal nutritional environment during critical stages of in utero development programs a higher risk of metabolic diseases later in life [3]. Offspring of diabetic pregnancy (ODP) are at risk for development of obesity and abnormal glucose metabolism during childhood, adolescence, and adulthood [4]. Thus, in addition to increased risk for the development of vascular disease in later life [5], obesity has been included as an outcome of interest in the offspring born to pregnancies complicated by diabetes [6]. Indeed, it is well known that fetal overgrowth has been related to increased transplacental transfer of glucose, stimulating the release of insulin by the fetal beta cell and subsequent macrosomia. Optimal maternal glucose control was shown to decrease perinatal mortality and morbidity, but whether or not improved glycemic control decreases the risk of obesity later in life is yet to be concluded. The recent decades are characterized by a large increase in maternal obesity and subsequently gestational diabetes mellitus and Type 2 diabetes [7]. From the Helsinki Birth Cohort Study, it was shown that maternal BMI (body mass index) directly correlates with health outcomes in infants, particularly cardiovascular disease and Type 2 diabetes [8]. Moreover, the Generation R Study demonstrated that higher weight gain in early pregnancy was associated with an adverse cardio-metabolic profile in infants, particularly mediated by childhood adiposity [9]. These results were confirmed through the Viva Project, a Boston-area prebirth cohort, where infants born to heavier mothers were shown to have more overall and central fat and greater cardio-metabolic risk, while infants of women with higher gestational weight gain had greater adiposity and higher leptin [10]. The worst outcomes are usually observed when nutritional conditions during gestation that have induced adaptive responses in the fetus and neonate, differ from consecutive postnatal nutrition (referred to as "nutritional mismatch" between early in utero life and adulthood) [11,12]. Metabolic diseases such as obesity, Type 2 diabetes and hypertension are the main diseases studied in the context of DOHaD, but many other functions are affected. Thus, in humans, early "conditioning processes" [13] were shown also to affect, among others, bones [14], psychiatric health [15] or fertility [16].

Most data in humans are based on epidemiological evidences from large cohort studies. The exploration of mechanisms leading to $\mathrm{DOHaD}$ and possible nutritional corrections during pregnancy or in the early neonatal period to reverse an inadequate programming can be achieved using animal models. Understanding key similarities, differences and limitations of various animal models used to study DOHaD is critical for translating animal findings to humans. Particular interest is given to the placentation [17] as the placenta is a key element for conveying information on maternal metabolism to the fetus [18-20].

\section{Choice of Animal Models}

As a consequence of obvious ethical considerations concerning what is feasible or not in the field of human biomedical research, animal models are of critical importance. The choice of one animal model over another is important and will depend on its similarity to the human being in terms of anatomy, physiology and metabolism, but also length of gestation, litter size, weight at birth, which is essential for inferring relevant information for possible application to the clinical context (Table 1). Animal models are particularly helpful for studies in the field of fetal programming (or DOHaD); indeed they allow us to clarify the critical windows of development, with exposure windows ranging from the preconception period and/or implantation until the postnatal period (breastfeeding), alone or altogether or through nutritional mismatch. They also allow the study of the effects of different types of maternal conditions (in utero exposures) such as under, over- and malnutrition, and/or maternal metabolic status (obesity and/or diabetes), among others (food pollutants, maternal stress ... ). 
Table 1. Pertinence of animal models and availability of tools classified from - (very little advantages) to ++++ (very advantageous or largely available). ?: no (or very few) data available; NA: not applicable. It must be noted that with the development of genome editing in mammalian species, transgenic models are quickly becoming easily available and reasonably priced in non-rodent animals.

\begin{tabular}{|c|c|c|c|c|c|c|c|}
\hline Criteria & Mice & Rats & Rabbits & Pigs & Ruminants & $\begin{array}{l}\text { Non-Human } \\
\text { Primates }\end{array}$ & Comments \\
\hline Cost & ++++ & & +++ & + & + & - & The cost of mice being lower, more groups can be developed. \\
\hline Nutrition & +++ & +++ & + & ++++ & - & ++++ & $\begin{array}{l}\text { Pigs have a digestive tract very similar to humans. Mice and rats can tolerate high } \\
\text { fat diets. Pig and rabbit lipid metabolism are close to humans. }\end{array}$ \\
\hline $\begin{array}{l}\text { Pre-implantation } \\
\text { development }\end{array}$ & +++ & ? & +++ & ? & ++ & ++ & $\begin{array}{c}\text { The embryonic genome activation takes place at the } 8-16 \text { cell stages in all species, } \\
\text { including humans, but for mice ( } 2 \text { cell stage). Mice are the best studied for } \\
\text { preimplantation development. }\end{array}$ \\
\hline Blastocyst stage & +++ & & +++ & ++ & ++ & NA & $\begin{array}{l}\text { Detailed knowledge of mice development is available. Rabbit blastocysts are used } \\
\text { for fine analysis of gastrulation. They yield enough cells for individual embryo } \\
\text { analysis. }\end{array}$ \\
\hline $\begin{array}{l}\text { Placental } \\
\text { physiology }\end{array}$ & +++ & & +++ & & ++ & ++++ & $\begin{array}{l}\text { Primates, rabbits and rodents possess a hemochorial placentation (rabbit placenta } \\
\text { being closest to humans). Ruminant and pig placenta are different. }\end{array}$ \\
\hline Fetal development & ++ & & ++ & ++ & +++ & ++++ & $\begin{array}{l}\begin{array}{l}\text { Polycotous species are less representative for human development compared to } \\
\text { monocotous species. }\end{array}\end{array}$ \\
\hline Management & ++++ & ++++ & ++++ & ++ & +++ & ++ & $\begin{array}{l}\text { Small species are highly manageable, with short intergenerational intervals. In } \\
\text { larger animals, ultrasound imaging of fetal growth is easily performed. }\end{array}$ \\
\hline Lactation & ++ & +++ & ++++ & ++++ & +++ & +++ & $\begin{array}{l}\text { In rabbits, suckling occurs only once a day, the study of milk intake and milk } \\
\text { production easy. The rat "pup in the cup" model exists only in the rat. }\end{array}$ \\
\hline Acceptability & ++++ & ++++ & ++++ & +++ & +++ & $+/-$ & Mice and rats are the most acceptable. \\
\hline Genomic tools & ++++ & +++ & ++ & +++ & +++ & +++ & $\begin{array}{c}\text { Genomic and epigenetic tools and antibodies remain most available in mice, } \\
\text { although possibilities increase in other species. }\end{array}$ \\
\hline Transgenic models & ++++ & - & ++ & ++ & + & - & $\begin{array}{c}\text { Transgenic mice models are largely available but transgenic models are also } \\
\text { available in rabbits and pigs. }\end{array}$ \\
\hline \multicolumn{8}{|c|}{ Programming outcomes that are identified through the measurements of physiological parameters in the offspring } \\
\hline Overweight & yes & yes & yes & yes & yes & yes & $\begin{array}{l}\text { The ruminants have a different glucose metabolism from monogastric species and } \\
\text { do not become diabetic. }\end{array}$ \\
\hline Hypertension & yes & yes & yes & yes & yes & yes & \\
\hline Diabetes & yes & yes & yes & yes & & yes & \\
\hline Behavior & yes & yes & & & yes & yes & \\
\hline
\end{tabular}


Placentation in humans is classified as hemochorial, i.e., the trophoblast is in direct contact with the maternal blood. Human trophoblast is considered the most invasive of all hemochorial placentas with very deep invasion of the maternal uterine wall to reach the maternal arteries. Direct contact with maternal blood, however, only occurs at the end of the first trimester. Non-human primates, rodents and lagomorphs (rabbits) also possess a hemochorial placenta. In the murine model, however, the placenta initially derives from the yolk sack and its definitive placentation only occurs in mid-gestation (total gestation time: 19-20 days) with a very limited invasion [21]. Other model species, such as sheep or pigs, possess an epitheliochorial placenta, which means that the placenta is just apposed on the maternal endometrium, with a concomitant thinning of the six trophoblastic and endometrial cell layers and extensive interdigitation of maternal and fetal tissues, which largely increase exchange surface.

Mice are the most commonly used animal models worldwide, providing a low cost, easy to handle, ethically acceptable option. They also provide ample access to genomic tools and transgenic lines. The discoid hemotrichorial placentation and the developmental and epigenetic processes are well described in these species at all stages of gestation. Limitations of this model include its small size, large number of embryos per litter and very short length of gestation (18-19 days), making it difficult to perform in vivo imaging and longitudinal sampling, and study chronic perturbations at specific stages of gestation. Given recent developments allowing genetic modifications in non-rodent models, additional animal models are increasing in popularity [22-24]. Moreover, their anatomical and physiological properties present advantages that can justify their use even without the use of genetic modifications, and ample knowledge and tools are becoming increasingly available [25].

Rabbits have been long used as animal models in toxicology. Their lipid metabolism is also closer to that of humans than mice [26]. Rabbits are particularly suitable for studies on the blastocyst because of their large size, allowing embryonic genome analyses in single embryos and easy analysis of gastrulation stages (because gastrulation begins before implantation in the rabbit) $[27,28]$. Their placental structure (discoid hemodichorial as opposed to hemotrichorial in mice) is closest to that of humans (discoid hemodichorial at early stages and hemomonochorial in late pregnancy) [29,30]. The adult size of rabbits enables the use of ultrasound imaging techniques for the monitoring of fetal development as in pregnant women [30,31]. It is a very docile species that reproduces easily with relatively short reproductive cycles and a lifetime that is long enough for exploring the occurrence of chronic diseases in offspring. Limitations of this model include the fact that it is a polytocous (several young rabbits per litter) species and the fragility of the offspring litter around weaning.

Sheep are human-sized animals with a long gestational period (five months) and usually a monotocous species (mostly one or two lambs per litter) as in humans. At term, the lamb weighs about the same as a human fetus and this has contributed to the popularity of this model in obstetrical research [30]. Sheep are easy to handle and pregnant animals tolerate invasive procedures aimed at reducing or evaluating fetal responses to different environments. Therefore sophisticated techniques have been developed for functional studies in utero after full recovery from anesthesia and surgery [18,32]. As a result, the available knowledge on fetal physiology is greater for sheep than any other species. The main disadvantages of this model are that sheep have a very different placentation (cotyledonary-type epitheliochorial placenta) than humans and also that they are ruminants with a very different digestive physiology and lower glycaemia than monogastric species. They are also expensive and housing, care and use of sheep is highly regulated by government agencies such as in the U.S. and Europe.

Pigs are considered to be one of the best domestic animal models for human nutrition due to their omnivorous diet, and are widely used because of the close resemblance between their gastro-intestinal tract and that of humans. Pigs are excellent for studying the environment of early stages of fertilization and early development. Their size makes sample preparations for proteomic analysis very easy. Limitations of this model include the fact that it is a polycotous species, with a diffuse epitheliochorial placenta that is different from humans. Their breeding is also costly and the adult animals are difficult to handle. Although their placentation is very different from that of humans, pigs remain a good 
post-natal model for intrauterine growth retardation (IUGR) as this condition occurs spontaneously in most litters, so that full siblings can be used as controls.

Non-human primates could be considered as the gold standard due to their important similarities to humans. However, their use for biomedical research is greatly limited by their behavioral and social organization, raising important ethical questions, as well as their elevated cost.

Through animal models, we can observe the subsequent long-term phenotypes of offspring (physiological, cardio-metabolic and behavioral characteristics) and explain the molecular mechanisms by transversal and multidisciplinary approaches. The most common species used in this field are rodents, as well as rabbits (lagomorphs), sheep, pigs and non-human primates, depending on the experimental approaches and tools used to observe in offspring the effects of maternal conditions.

\section{Maternal Conditions Associated with DOHaD}

It is now well-established from epidemiological studies that both early nutrition and maternal metabolic status during pregnancy play a seminal role in determining the offspring's long-term health and metabolism. These maternal conditions affect the growth trajectory and the function of the feto-placental unit, leading to various birth sizes from small (SGA) to large for gestational age (LGA), correlated to different adverse health outcomes at adulthood (Figure 1).

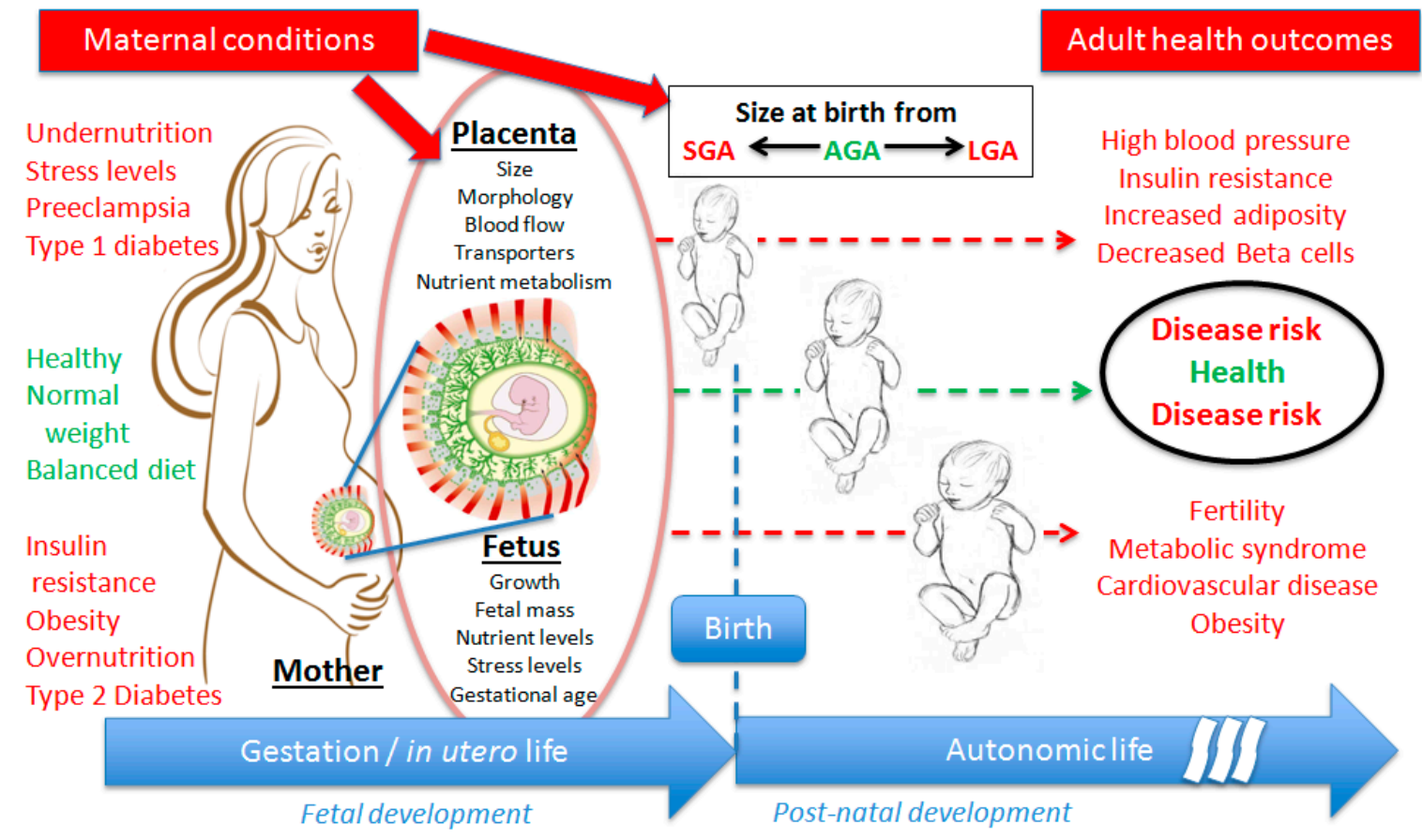

Figure 1. Schematic representation of the $\mathrm{DOHaD}$ (developmental origins of health and diseases) concept in human beings, showing the effects of several maternal conditions (non exhaustive) during the gestation on feto-placental unit development (affected parameters), leading to particular birth size from SGA (small for gestational age) to LGA (large for gestational age), and the most observed outcomes in terms of health at adulthood.

\subsection{Placental Insufficiency}

In humans in westernized countries, IUGR is rarely the consequence of malnutrition but is rather due to placental insufficiency due to abnormal placental vascularization (such as preeclampsia or pregnancy-induced hypertension) [33]. In preeclampsia, a disease specific to humans with no known equivalent syndrome in animals but for some non-human primate species, spiral arteries do not undergo physiological remodeling into the myometrial segment through trophoblast invasion, 
which explains the utero-placental ischemia and inflammatory response (Figure 2). Animal models of surgically-induced placental vascular restriction remain unsatisfactory [34]. Nevertheless, the use of spontaneous or less invasively-induced models of IUGR of vascular origin in pigs or sheep has demonstrated that the same pattern of long-term effects were observed as for maternal undernutrition [35].

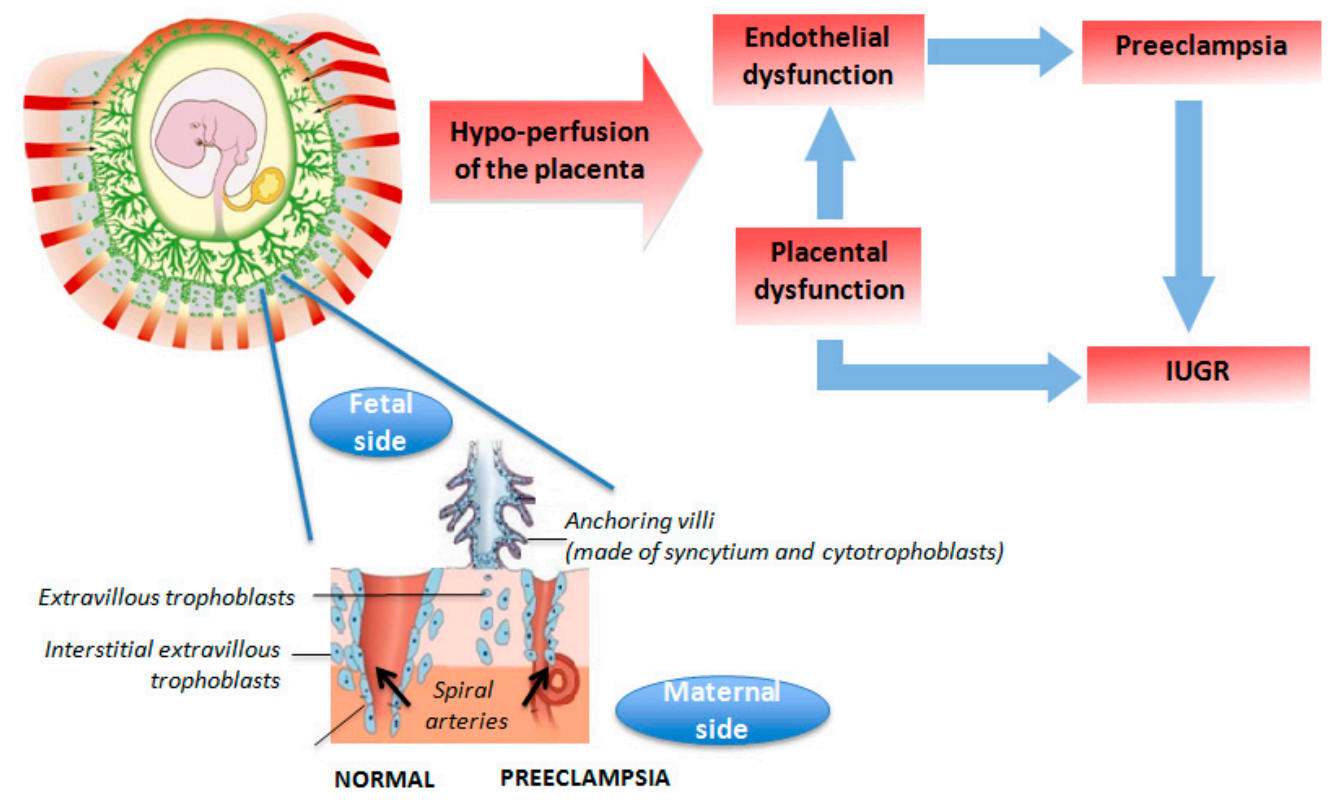

Figure 2. Schematic representation of materno-fetal vascularization in human normal pregnancy or preeclampsia conditions leading to intrauterine growth retardation (IUGR).

\subsection{Maternal Malnutrition}

Although maternal malnutrition is not the most common cause of fetal undernutrition, nutrition during pregnancy plays a significant role in both fuel supply to the fetus and placentation. Vasculogenesis and angiogenesis are key events for the development of the placenta. Placental vascularization progresses throughout gestation and is controlled by both physical and chemical factors such as oxygen and growth factors [36,37]. The maternal environment is able to modulate placental vascularization and alter the transport of respiratory oxygen and nutrients. For example, in ewes underfed during gestation, the placental expression of vascular endothelial growth factor (VEGF) receptor transcripts was reduced by $50 \%$ on day 130 compared to ewes that received standard diet, while VEGF transcripts remained unchanged [38]. Placental circulation, which is central to uterine and umbilical blood flows, is therefore an important player for the success of pregnancy.

In rodents, most experiments that induce global undernutrition or protein restriction during gestation, lead to fetal IUGR with subsequent increase in the incidence of hypertension, excess adipose tissue deposition, abnormal glucose metabolism and dyslipidemia in adult offspring [39] (Figure 3). In mice, a reduction in longevity of $32 \%$ was observed in male offspring born to females submitted to a low protein diet during gestation and fed a high fat/high carbohydrates diet after weaning compared to controls fed a normal diet [40]. In the same study, some of the dams were fed a low protein diet during lactation that slowed down post-natal growth. Thus, offspring born to dams fed normally during gestation and with reduced neonatal growth had the longest lifespan, underlining the importance of the immediate post-natal nutrition for conditioning post-natal phenotype [40]. Similar observations in several model species have confirmed the robustness of these phenomena in mammals [41,42]. 


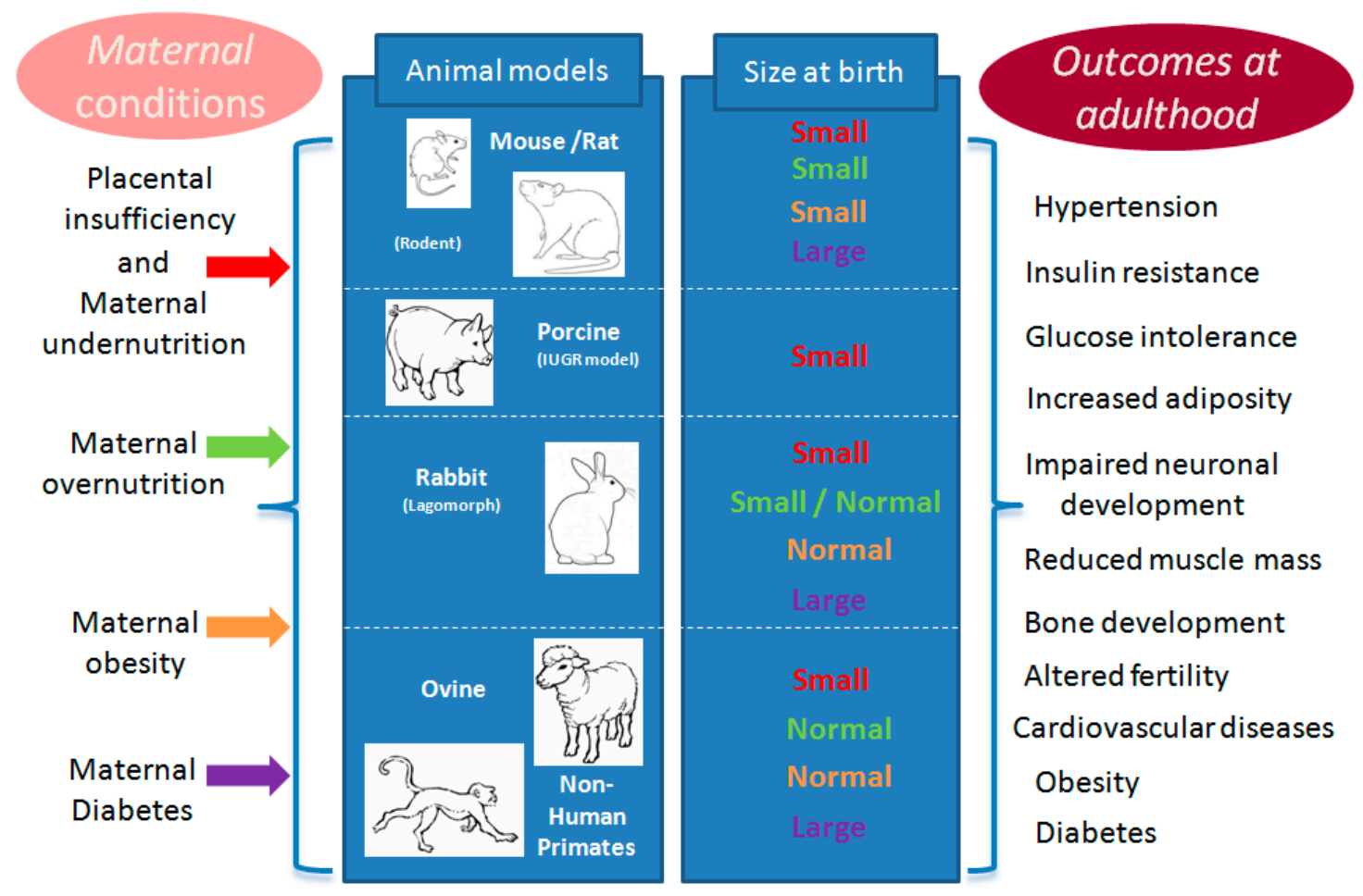

Figure 3. Schematic representation of prevalent models for studying exposures to maternal nutrition or metabolism during gestation, the consecutive and species-specific birth size, and the usual outcomes in terms of health for all animal models at adulthood. One color is attributed to each kind of exposure: red for placental insufficiency and maternal malnutrition (undernutrition), green for over nutrition, orange for obesity and purple for diabetes. The column "size at birth" gave the fetal response to each kind of maternal conditions in term of size compared to control conditions in the same species. The same color is used for the "small" or "normal" or "large" response to each corresponding maternal conditions compared to normal (or expected) size for same age in the same species.

These effects, however, are most often only observed in adult animals and so caution should be taken when interpreting growth outcomes from studies limited to the neonatal period or infancy. In general, prolonged and relatively severe maternal undernutrition is necessary to affect birth weight and post-natal growth in sheep [43] and pigs [44]. Undernutrition at the beginning of gestation, however, can affect offspring body composition and survival at birth with or without affecting birth weight per se, but also adult metabolism, production and body composition. As for examples of the latter, increased adiposity is often observed [45]. Moreover, increased glucocorticoid sensitivity was observed in sheep after maternal undernutrition in early pregnancy [46]. In another experiment, maternal undernutrition of Large White sows from mating to 50 days of pregnancy did not affect body weight, lean tissue and adipose tissue yield in offspring, whereas the composition of muscle in terms of myofiber type was slightly affected [47]. A maternal protein restriction, however, was shown to reduce the lean and increase the fat contents of six-month old offspring with a tendency for reduced number of muscle myofibers associated with reduced expression of IGF2 mRNA (messenger RNA of Insulin-like growth factor 2 gene) [48].

\subsection{Maternal Overnutrition and/or Obesity}

Although one would expect that maternal overnutrition would always result in fetal overgrowth, but this is not always the case. As a matter of fact, in many species, maternal overnutrition or obesity results in IUGR through mechanisms that affect blood flow to the placenta [49]. For example, over-nourished pregnant young sheep are characterized by an increase in umbilical artery Doppler 
indices at mid-gestation, which precede the reduction in fetal growth velocity [49]. Feeding an obesogenic diet before breeding and throughout gestation and lactation was shown to induce obesity, hyperglycaemia and hyperinsulinemia in female rats, which induced subsequent insulin resistance in their male offspring [50,51] (Figure 3). Similar effects were observed in rabbits [52]. Dietary-induced obesity gives rise to placental inflammation at term. Indeed, this placental inflammation has been observed earlier in pregnancy in a sheep model of overfeeding-induced obesity and was associated with significant fetal consequences including higher plasma content of free fatty acids, triglycerides and cholesterol [53]. In another sheep study, maternal obesity increased collagen content and cross-linking in offspring muscle, which might be partially due to reduced collagen remodeling, favoring insulin resistance [54]. Moreover, when female rats were fed an obesogenic diet before conception but not during pregnancy, maternal treatment also enhanced offspring response to a high fat diet [51]. These data demonstrate that maternal obesity conditions the offspring to obesity, even if nutritional intake is controlled during pregnancy. More recent studies also indicate that not only metabolic disorders are observed in offspring, but also behavioral abnormalities such as hyperactivity [55]. A study in non-human primates showed that maternal dietary-induced obesity caused epigenetic modifications in offspring hepatic genes that could alter metabolism and predispose them to obesity later in life [56]. In adult ewes, dietary-induced obesity was associated with offspring macrosomia [57], hyperglycemia and hyperinsulinemia with markedly increased pancreatic weight and beta cell numbers [58]. Maternal obesity was also shown to downregulate fetal myogenesis at mid-gestation through the Wnt/beta-catenin signaling pathway (Wnt are secreted glycolipoproteins via the transcription co-activator beta-catenin) [59]. As demonstrated by these animal studies, maternal overnutrition affects offspring body composition through multiple mechanisms, requiring a multi-faceted approach for the prevention of developmentally programmed obesity.

\subsection{Maternal Diabetes}

Models of maternal diabetes are associated with various degrees of pancreatic dysfunction and insulin resistance and thus there is a large phenotypic variation in offspring, as described in human medicine. As an example, streptozotocin injection in female rats during gestation, inducing the destruction of pancreatic beta cells, is associated with fetal macrosomia and subsequent hyperglycemia and hyperinsulinemia in offspring [60]. Conversely in alloxan-induced diabetic rabbits, the birth weights of fetuses from severely diabetic rabbit does were only slightly lower than those of controls, whereas offspring from mildly diabetic does had birth weights that were significantly higher than controls [61] (Figure 3). Still, in alloxan-induced diabetic rabbits, maternal hyperglycemia during the pre-implantation period is correlated with an increase in advanced glycation end-product formation (oxidative stress) in the uterine environment and the embryo itself, compromising further development and health outcomes [62]. When glucose is infused in rats in late gestation, this provokes hyperglycemia-induced disorders in insulin secretion in offspring [63,64]. Similarly, in sheep, while diabetes does not occur naturally and is not chemically-induced, an artificial transient maternal hyperglycemia in the last third of gestation can be used to explore the effect on fetal growth (macrosomia) and further offspring health outcomes [65].

Finally, transgenic pigs have been developed to provide systemic insights into developmental consequences of maternal hyperglycemia when important issues of early human development cannot be adequately simulated in mouse models [66]; they exhibited decreased beta cell mass and lower fasting insulin levels, with a stable diabetic phenotype compared with littermate controls [67]. These models will be very useful to study the effects of maternal diabetes on offspring development.

\section{Interventional Experiments for Remediation of Long Term Effects}

As summarized through some examples above, there is rapidly emerging evidence regarding the adverse effects of maternal obesity and diabetes in the DOHaD in both humans and animal 
models. There is a strong need for implementing prenatal and postnatal prevention strategies. Various approaches have been tested and several are highlighted below.

In humans, prevention strategies are the basis of the 1000 days initiative, which aims to improve nutrition recommendations for mothers and children from the beginning of woman's pregnancy until the second birthday of her child [68].

Switching obese rats from an obesogenic to a standard diet one month before breeding and maintaining this diet until delivery considerably improved adult offspring outcomes [69]. Similar results were obtained in pregnant obese ewes that were returned to a diet according to their nutritional requirements early in gestation [69]. In another attempt in mice, increasing the $n-3 / n-6$ polyunsaturated fatty acid (PUFA) ratio of maternal plasma reduced the consequences of maternal obesity-associated inflammation during pregnancy and prevented adverse fetal metabolic outcomes [70]. The effects of exercise before and throughout gestation in obese female rats have been tested on offspring outcome [69]: maternal exercise in obese rats decreased body weight, fat and adiposity indices in male offspring at postnatal day 650. Moreover, exercise also improved the adverse metabolic outcomes in offspring.

There is ample evidence in animal models that the periconceptional environment plays an important role in conditioning the offspring's post-natal health [71-75]. Thus, attempts to correct the nutritional environment of the mother before conception have been performed. The response to an adverse maternal nutritional environment depends on the ability of the embryo to adapt itself to such an environment, which is acquired before implantation, as demonstrated by studies in mice submitted either to low protein [75] or high fat diets [76]. Thus, correcting nutritional imbalance in women before the establishment of pregnancy might be included in the strategies to prevent child and adult obesity. Moreover, still in the periconceptional context, recent data in mouse models indicate that the father's diet and/or metabolic condition (dyslipidemia, glucose intolerance, and obesity) can affect epigenetic marks in the spermatozoa and induce altered metabolism in offspring [77-80]. This indicates that not only the woman, but also her male partner need to be considered when trying to prevent childhood obesity before conception [81].

\section{Conclusions}

In conclusion, the maternal conditions experienced during in utero life lead to adaptive changes of structure and function of placenta and of vital organs in the fetus. Most of the experimental studies in fetal programming have been driven to better characterize the impact of maternal conditions during gestation on offspring health from the prenatal stage (in utero life) to adulthood. Most of these effects are induced very precociously in life and may involve epigenetic processes (but not only such processes). The long-term health outcomes in offspring very often include insulin resistance, excess adiposity and cardio-metabolic disorders, whatever the studied species (rats, guinea pigs, mice, rabbit, sheep, pigs, and non-human primates). Research on $\mathrm{DOHaD}$ should now be intensified to identify the mechanisms leading to the observed effects in adulthood.

Animal models are essential to the understanding of these mechanisms and the development of interventional therapies before they are implemented in humans.

Remediating long-term consequences might be possible using pre-conceptional, gestational or perinatal interventions. These strategies have been proven effective in the past as shown using folic acid and n-3 PUFA that have been used to improve the metabolic or inflammatory profile of the mother (from the preconception period to the weaning of the offspring).

All remediation efforts need to be challenged to evaluate mechanisms leading to both short and long-term effects including functional adaptability, susceptibility, and reversibility. In doing so, it is important to remember that non-rodent animals should not be neglected, as they are often more physiologically-appropriate models to human conditions. This review highlights specific maternal, placental and fetal characteristics associated with $\mathrm{DOHaD}$ and provides guidance in the selection of appropriate animal models to understand and prevent developmentally programmed disease. 
Acknowledgments: The authors of this paper are members of COST (European Cooperation in Science and Technology) Action BM1308 Sharing Advances on Large Animal Models (http://www. salaam.genzentrum.lmu.de).

Author Contributions: Pascale Chavatte-Palmer wrote the manuscript; Delphine Rousseau-Ralliard and Anne Tarrade provided relevant information, discussed the data, and corrected the manuscript; and Delphine Rousseau-Ralliard revised the manuscript.

Conflicts of Interest: There is no conflict of interest related to the content of this paper. None of the authors have received honorarium.

\section{References}

1. Barker, D.J.; Osmond, C. Infant mortality, childhood nutrition, and ischaemic heart disease in england and wales. Lancet 1986, 1, 1077-1081. [CrossRef]

2. Hales, C.N.; Barker, D.J.; Clark, P.M.; Cox, L.J.; Fall, C.; Osmond, C.; Winter, P.D. Fetal and infant growth and impaired glucose tolerance at age 64. BMJ 1991, 303, 1019-1022. [CrossRef] [PubMed]

3. Alfaradhi, M.Z.; Ozanne, S.E. Developmental programming in response to maternal overnutrition. Front. Genet. 2011, 2, 27. [CrossRef] [PubMed]

4. Metzger, B.E. Long-term outcomes in mothers diagnosed with gestational diabetes mellitus and their offspring. Clin. Obstet. Gynecol. 2007, 50, 972-979. [CrossRef] [PubMed]

5. Manderson, J.G.; Mullan, B.; Patterson, C.C.; Hadden, D.R.; Traub, A.I.; McCance, D.R. Cardiovascular and metabolic abnormalities in the offspring of diabetic pregnancy. Diabetologia 2002, 45, 991-996. [CrossRef] [PubMed]

6. Dabelea, D. The predisposition to obesity and diabetes in offspring of diabetic mothers. Diabetes Care 2007, 30, S169-S174. [CrossRef] [PubMed]

7. Catalano, P.M.; Hauguel-De Mouzon, S. Is it time to revisit the pedersen hypothesis in the face of the obesity epidemic? Am. J. Obstet. Gynecol. 2011, 204, 479-487. [CrossRef] [PubMed]

8. Eriksson, J.G.; Sandboge, S.; Salonen, M.K.; Kajantie, E.; Osmond, C. Long-term consequences of maternal overweight in pregnancy on offspring later health: Findings from the helsinki birth cohort study. Ann. Med. 2014, 46, 434-438. [CrossRef] [PubMed]

9. Gaillard, R.; Steegers, E.A.; Franco, O.H.; Hofman, A.; Jaddoe, V.W. Maternal weight gain in different periods of pregnancy and childhood cardio-metabolic outcomes. The generation $\mathrm{r}$ study. Int. J. Obes. 2015, 39, 677-685. [CrossRef] [PubMed]

10. Perng, W.; Gillman, M.W.; Mantzoros, C.S.; Oken, E. A prospective study of maternal prenatal weight and offspring cardiometabolic health in midchildhood. Ann. Epidemiol. 2014, 24. [CrossRef] [PubMed]

11. Bateson, P.; Barker, D.; Clutton-Brock, T.; Deb, D.; D’Udine, B.; Foley, R.A.; Gluckman, P.; Godfrey, K.; Kirkwood, T.; Lahr, M.M.; et al. Developmental plasticity and human health. Nature 2004, 430, 419-421. [CrossRef] [PubMed]

12. Hales, C.N.; Barker, D.J. The thrifty phenotype hypothesis. Br. Med. Bull. 2001, 60, 5-20. [CrossRef] [PubMed]

13. Hanson, M.A.; Gluckman, P.D. Early developmental conditioning of later health and disease: Physiology or pathophysiology? Physiol. Rev. 2014, 94, 1027-1076. [CrossRef] [PubMed]

14. Goodfellow, L.R.; Earl, S.; Cooper, C.; Harvey, N.C. Maternal diet, behavior and offspring skeletal health. Int. J. Environ. Res. Public Health 2010, 7, 1760-1772. [CrossRef] [PubMed]

15. Khandaker, G.M.; Dibben, C.R.; Jones, P.B. Does maternal body mass index during pregnancy influence risk of schizophrenia in the adult offspring? Obes. Rev. Off. J. Int. Assoc. Study Obes. 2012, 13, 518-527. [CrossRef] [PubMed]

16. Faure, C.; Dupont, C.; Chavatte-Palmer, P.; Gautier, B.; Levy, R.; Group, A.C. Are semen parameters related to birth weight? Fertil. Steril. 2015, 103, 6-10. [CrossRef] [PubMed]

17. Chavatte-Palmer, P.; Guillomot, M. Comparative implantation and placentation. Gynecol. Obstet. Investig. 2007, 64, 166-174. [CrossRef] [PubMed]

18. Fowden, A.L.; Moore, T. Maternal-fetal resource allocation: Co-operation and conflict. Placenta 2012, 33, e11-e15. [CrossRef] [PubMed]

19. Myatt, L. Placental adaptive responses and fetal programming. J. Physiol. 2006, 572, 25-30. [CrossRef] [PubMed] 
20. Tarrade, A.; Panchenko, P.; Junien, C.; Gabory, A. Placental contribution to nutritional programming of health and diseases: Epigenetics and sexual dimorphism. J. Exp. Biol. 2015, 218, 50-58. [CrossRef] [PubMed]

21. Malassine, A.; Frendo, J.L.; Evain-Brion, D. A comparison of placental development and endocrine functions between the human and mouse model. Hum. Reprod. Update 2003, 9, 531-539. [CrossRef] [PubMed]

22. Aigner, B.; Renner, S.; Kessler, B.; Klymiuk, N.; Kurome, M.; Wunsch, A.; Wolf, E. Transgenic pigs as models for translational biomedical research. J. Mol. Med. 2010, 88, 653-664. [CrossRef] [PubMed]

23. Whitelaw, C.B.; Sheets, T.P.; Lillico, S.G.; Telugu, B.P. Engineering large animal models of human disease. J. Pathol. 2016, 238, 247-256. [CrossRef] [PubMed]

24. Cost Action BM1308-Sharing Advances on Large Animal Models (SALAAM). Available online: http:/ /www.salaam.genzentrum.lmu.de/ (accessed on 11 March 2016).

25. Swanson, K.S.; Mazur, M.J.; Vashisht, K.; Rund, L.A.; Beever, J.E.; Counter, C.M.; Schook, L.B. Genomics and clinical medicine: Rationale for creating and effectively evaluating animal models. Exp. Biol. Med. 2004, 229, 866-875.

26. Paigen, B. Genetics of responsiveness to high-fat and high-cholesterol diets in the mouse. Am. J. Clin. Nutr. 1995, 62, 458S-462S. [PubMed]

27. Carter, A.M. Animal models of human placentation-A review. Placenta 2007, 28, S41-S47. [CrossRef] [PubMed]

28. Fischer, B.; Chavatte-Palmer, P.; Viebahn, C.; Navarrete Santos, A.; Duranthon, V. Rabbit as a reproductive model for human health. Reproduction 2012, 144, 1-10. [CrossRef] [PubMed]

29. Furukawa, S.; Kuroda, Y.; Sugiyama, A. A comparison of the histological structure of the placenta in experimental animals. J. Toxicol. Pathol. 2014, 27, 11-18. [CrossRef] [PubMed]

30. Morel, O.; Laporte-Broux, B.; Tarrade, A.; Chavatte-Palmer, P. The use of ruminant models in biomedical perinatal research. Theriogenology 2012, 78, 1763-1773. [CrossRef] [PubMed]

31. Lecarpentier, E.; Morel, O.; Tarrade, A.; Dahirel, M.; Bonneau, M.; Gayat, E.; Evain-Brion, D.; Chavatte-Palmer, P.; Tsatsaris, V. Quantification of utero-placental vascularization in a rabbit model of iugr with three-dimensional power doppler angiography. Placenta 2012, 33, 769-775. [CrossRef] [PubMed]

32. Ward, J.W.; Wooding, F.B.; Fowden, A.L. Ovine feto-placental metabolism. J. Physiol. 2004, 554, 529-541. [CrossRef] [PubMed]

33. Sibai, B.; Dekker, G.; Kupferminc, M. Pre-eclampsia. Lancet 2005, 365, 785-799. [CrossRef]

34. Neitzke, U.; Harder, T.; Schellong, K.; Melchior, K.; Ziska, T.; Rodekamp, E.; Dudenhausen, J.W.; Plagemann, A. Intrauterine growth restriction in a rodent model and developmental programming of the metabolic syndrome: A critical appraisal of the experimental evidence. Placenta 2008, 29, 246-254. [CrossRef] [PubMed]

35. McMillen, I.C.; MacLaughlin, S.M.; Muhlhausler, B.S.; Gentili, S.; Duffield, J.L.; Morrison, J.L. Developmental origins of adult health and disease: The role of periconceptional and foetal nutrition. Basic Clin. Pharmacol. Toxicol. 2008, 102, 82-89. [CrossRef] [PubMed]

36. Charnock-Jones, D.S.; Kaufmann, P.; Mayhew, T.M. Aspects of human fetoplacental vasculogenesis and angiogenesis. I. Molecular regulation. Placenta 2004, 25, 103-113. [CrossRef] [PubMed]

37. Kaufmann, P.; Mayhew, T.M.; Charnock-Jones, D.S. Aspects of human fetoplacental vasculogenesis and angiogenesis. Ii. Changes during normal pregnancy. Placenta 2004, 25, 114-126. [CrossRef] [PubMed]

38. Luther, J.; Milne, J.; Aitken, R.; Matsuzaki, M.; Reynolds, L.; Redmer, D.; Wallace, J. Placental growth, angiogenic gene expression, and vascular development in undernourished adolescent sheep. Biol. Reprod. 2007, 77, 351-357. [CrossRef] [PubMed]

39. Remacle, C.; Bieswal, F.; Bol, V.; Reusens, B. Developmental programming of adult obesity and cardiovascular disease in rodents by maternal nutrition imbalance. Am. J. Clin. Nutr. 2011, 94, 1846S-1852S. [CrossRef] [PubMed]

40. Ozanne, S.E.; Hales, C.N. Lifespan: Catch-up growth and obesity in male mice. Nature 2004, 427, 411-412. [CrossRef] [PubMed]

41. McMillen, I.C.; Robinson, J.S. Developmental origins of the metabolic syndrome: Prediction, plasticity, and programming. Physiol. Rev. 2005, 85, 571-633. [CrossRef] [PubMed]

42. Wu, G.; Bazer, F.W.; Wallace, J.M.; Spencer, T.E. Board-invited review: Intrauterine growth retardation: Implications for the animal sciences. J. Anim. Sci. 2006, 84, 2316-2337. [CrossRef] [PubMed] 
43. Field, M.E.; Anthony, R.V.; Engle, T.E.; Archibeque, S.L.; Keisler, D.H.; Han, H. Duration of maternal undernutrition differentially alters fetal growth and hormone concentrations. Domest. Animal Endocrinol. 2015, 51, 1-7. [CrossRef] [PubMed]

44. Morise, A.; Louveau, I.; Le Huerou-Luron, I. Growth and development of adipose tissue and gut and related endocrine status during early growth in the pig: Impact of low birth weight. Anim. Int. J. Anim. Biosci. 2008, 2, 73-83. [CrossRef] [PubMed]

45. Bispham, J.; Gopalakrishnan, G.S.; Dandrea, J.; Wilson, V.; Budge, H.; Keisler, D.H.; Broughton Pipkin, F.; Stephenson, T.; Symonds, M.E. Maternal endocrine adaptation throughout pregnancy to nutritional manipulation: Consequences for maternal plasma leptin and cortisol and the programming of fetal adipose tissue development. Endocrinology 2003, 144, 3575-3585. [CrossRef] [PubMed]

46. Mostyn, A.; Symonds, M.E. Early programming of adipose tissue function: A large-animal perspective. Proc. Nutr. Soc. 2009, 68, 393-400. [CrossRef] [PubMed]

47. Bee, G. Effect of early gestation feeding, birth weight, and gender of progeny on muscle fiber characteristics of pigs at slaughter. J. Anim. Sci. 2004, 82, 826-836. [PubMed]

48. Rehfeldt, C.; Stabenow, B.; Pfuhl, R.; Block, J.; Nurnberg, G.; Otten, W.; Metges, C.C.; Kalbe, C. Effects of limited and excess protein intakes of pregnant gilts on carcass quality and cellular properties of skeletal muscle and subcutaneous adipose tissue in fattening pigs. J. Anim. Sci. 2012, 90, 184-196. [CrossRef] [PubMed]

49. Carr, D.J.; Aitken, R.P.; Milne, J.S.; David, A.L.; Wallace, J.M. Fetoplacental biometry and umbilical artery doppler velocimetry in the overnourished adolescent model of fetal growth restriction. Am. J. Obstet. Gynecol. 2012, 207. [CrossRef] [PubMed]

50. Nivoit, P.; Morens, C.; Van Assche, F.A.; Jansen, E.; Poston, L.; Remacle, C.; Reusens, B. Established diet-induced obesity in female rats leads to offspring hyperphagia, adiposity and insulin resistance. Diabetologia 2009, 52, 1133-1142. [CrossRef] [PubMed]

51. Shankar, K.; Harrell, A.; Liu, X.; Gilchrist, J.M.; Ronis, M.J.; Badger, T.M. Maternal obesity at conception programs obesity in the offspring. Am. J. Physiol. Regul. Integr. Comp. Physiol. 2008, 294, R528-R538. [CrossRef] [PubMed]

52. Picone, O.; Laigre, P.; Fortun-Lamothe, L.; Archilla, C.; Peynot, N.; Ponter, A.A.; Berthelot, V.; Cordier, A.G.; Duranthon, V.; Chavatte-Palmer, P. Hyperlipidic hypercholesterolemic diet in prepubertal rabbits affects gene expression in the embryo, restricts fetal growth and increases offspring susceptibility to obesity. Theriogenology 2011, 75, 287-299. [CrossRef] [PubMed]

53. Zhu, M.J.; Du, M.; Nathanielsz, P.W.; Ford, S.P. Maternal obesity up-regulates inflammatory signaling pathways and enhances cytokine expression in the mid-gestation sheep placenta. Placenta 2010, 31, 387-391. [CrossRef] [PubMed]

54. Huang, Y.; Zhao, J.X.; Yan, X.; Zhu, M.J.; Long, N.M.; McCormick, R.J.; Ford, S.P.; Nathanielsz, P.W.; Du, M. Maternal obesity enhances collagen accumulation and cross-linking in skeletal muscle of ovine offspring. PLoS ONE 2012, 7, e31691. [CrossRef] [PubMed]

55. Fernandes, C.; Grayton, H.; Poston, L.; Samuelsson, A.M.; Taylor, P.D.; Collier, D.A.; Rodriguez, A. Prenatal exposure to maternal obesity leads to hyperactivity in offspring. Mol. Psychiatr. 2012, 17, 1159-1160. [CrossRef] [PubMed]

56. Aagaard-Tillery, K.M.; Grove, K.; Bishop, J.; Ke, X.; Fu, Q.; McKnight, R.; Lane, R.H. Developmental origins of disease and determinants of chromatin structure: Maternal diet modifies the primate fetal epigenome. J. Mol. Endocrinol. 2008, 41, 91-102. [CrossRef] [PubMed]

57. Ford, S.P.; Zhang, L.; Zhu, M.; Miller, M.M.; Smith, D.T.; Hess, B.W.; Moss, G.E.; Nathanielsz, P.W.; Nijland, M.J. Maternal obesity accelerates fetal pancreatic beta-cell but not alpha-cell development in sheep: Prenatal consequences. Am. J. Physiol. Regul. Integr. Comp. Physiol. 2009, 297, R835-R843. [CrossRef] [PubMed]

58. Zhang, L.; Long, N.M.; Hein, S.M.; Ma, Y.; Nathanielsz, P.W.; Ford, S.P. Maternal obesity in ewes results in reduced fetal pancreatic beta-cell numbers in late gestation and decreased circulating insulin concentration at term. Domest. Anim. Endocrinol. 2011, 40, 30-39. [CrossRef] [PubMed]

59. Tong, J.; Zhu, M.J.; Underwood, K.R.; Hess, B.W.; Ford, S.P.; Du, M. Amp-activated protein kinase and adipogenesis in sheep fetal skeletal muscle and 3t3-11 cells. J. Anim. Sci. 2008, 86, 1296-1305. [CrossRef] [PubMed] 
60. Lopez-Soldado, I.; Herrera, E. Different diabetogenic response to moderate doses of streptozotocin in pregnant rats, and its long-term consequences in the offspring. Exp. Diabesity Res. 2003, 4, 107-118. [CrossRef] [PubMed]

61. Neufeld, N.D.; Corbo, L.; Stoddard, A.; Klein, A.H.; Tadokoro, N. Oxygen consumption and guanosine diphosphate binding by fetal brown adipose tissue in diabetic pregnancy. Metab. Clin. Exp. 1989, 38, 831-836. [CrossRef]

62. Haucke, E.; Navarrete Santos, A.; Simm, A.; Henning, C.; Glomb, M.A.; Gurke, J.; Schindler, M.; Fischer, B.; Navarrete Santos, A. Accumulation of advanced glycation end products in the rabbit blastocyst under maternal diabetes. Reproduction 2014, 148, 169-178. [CrossRef] [PubMed]

63. Gauguier, D.; Bihoreau, M.T.; Ktorza, A.; Berthault, M.F.; Picon, L. Inheritance of diabetes mellitus as consequence of gestational hyperglycemia in rats. Diabetes 1990, 39, 734-739. [CrossRef] [PubMed]

64. Gauguier, D.; Bihoreau, M.T.; Picon, L.; Ktorza, A. Insulin secretion in adult rats after intrauterine exposure to mild hyperglycemia during late gestation. Diabetes 1991, 40, 109-114. [CrossRef] [PubMed]

65. Smith, N.A.; McAuliffe, F.M.; Quinn, K.; Lonergan, P.; Evans, A.C. Transient high glycaemic intake in the last trimester of pregnancy increases offspring birthweight and postnatal growth rate in sheep: A randomised control trial. BJOG Int. J. Obstet. Gynaecol. 2009, 116, 975-983. [CrossRef] [PubMed]

66. Wolf, E.; Braun-Reichhart, C.; Streckel, E.; Renner, S. Genetically engineered pig models for diabetes research. Transgen. Res. 2014, 23, 27-38. [CrossRef] [PubMed]

67. Renner, S.; Braun-Reichhart, C.; Blutke, A.; Herbach, N.; Emrich, D.; Streckel, E.; Wunsch, A.; Kessler, B.; Kurome, M.; Bahr, A.; et al. Permanent neonatal diabetes in ins(c94y) transgenic pigs. Diabetes 2013, 62, 1505-1511. [CrossRef] [PubMed]

68. The 1,000 days. Available online: http://thousanddays.org/ (accessed on 11 March 2016).

69. Nathanielsz, P.W.; Ford, S.P.; Long, N.M.; Vega, C.C.; Reyes-Castro, L.A.; Zambrano, E. Interventions to prevent adverse fetal programming due to maternal obesity during pregnancy. Nutr. Rev. 2013, 71, S78-S87. [CrossRef] [PubMed]

70. Heerwagen, M.J.; Stewart, M.S.; de la Houssaye, B.A.; Janssen, R.C.; Friedman, J.E. Transgenic increase in n-3/n-6 fatty acid ratio reduces maternal obesity-associated inflammation and limits adverse developmental programming in mice. PLoS ONE 2013, 8, e67791. [CrossRef] [PubMed]

71. Cetin, I.; Berti, C.; Calabrese, S. Role of micronutrients in the periconceptional period. Hum. Reprod. Update 2010, 16, 80-95. [CrossRef] [PubMed]

72. Dahlhoff, M.; Pfister, S.; Blutke, A.; Rozman, J.; Klingenspor, M.; Deutsch, M.J.; Rathkolb, B.; Fink, B.; Gimpfl, M.; Hrabe de Angelis, M.; et al. Peri-conceptional obesogenic exposure induces sex-specific programming of disease susceptibilities in adult mouse offspring. Biochim. Biophys. Acta 2014, 1842, 304-317. [CrossRef] [PubMed]

73. Fleming, T.P.; Kwong, W.Y.; Porter, R.; Ursell, E.; Fesenko, I.; Wilkins, A.; Miller, D.J.; Watkins, A.J.; Eckert, J.J. The embryo and its future. Biol. Reprod. 2004, 71, 1046-1054. [CrossRef] [PubMed]

74. Steegers-Theunissen, R.P.; Twigt, J.; Pestinger, V.; Sinclair, K.D. The periconceptional period, reproduction and long-term health of offspring: The importance of one-carbon metabolism. Hum. Reprod. Update 2013, 19, 640-655. [CrossRef] [PubMed]

75. Watkins, A.J.; Lucas, E.S.; Fleming, T.P. Impact of the periconceptional environment on the programming of adult disease. J. Dev. Orig. Health Dis. 2010, 1, 87-95. [CrossRef] [PubMed]

76. Sasson, I.E.; Vitins, A.P.; Mainigi, M.A.; Moley, K.H.; Simmons, R.A. Pre-gestational vs gestational exposure to maternal obesity differentially programs the offspring in mice. Diabetologia 2015, 58, 615-624. [CrossRef] [PubMed]

77. Carone, B.R.; Fauquier, L.; Habib, N.; Shea, J.M.; Hart, C.E.; Li, R.; Bock, C.; Li, C.; Gu, H.; Zamore, P.D.; et al. Paternally induced transgenerational environmental reprogramming of metabolic gene expression in mammals. Cell 2010, 143, 1084-1096. [CrossRef] [PubMed]

78. Jimenez-Chillaron, J.C.; Isganaitis, E.; Charalambous, M.; Gesta, S.; Pentinat-Pelegrin, T.; Faucette, R.R.; Otis, J.P.; Chow, A.; Diaz, R.; Ferguson-Smith, A.; et al. Intergenerational transmission of glucose intolerance and obesity by in utero undernutrition in mice. Diabetes 2009, 58, 460-468. [CrossRef] [PubMed] 
79. Martinez, D.; Pentinat, T.; Ribo, S.; Daviaud, C.; Bloks, V.W.; Cebria, J.; Villalmanzo, N.; Kalko, S.G.; Ramon-Krauel, M.; Diaz, R.; et al. In utero undernutrition in male mice programs liver lipid metabolism in the second-generation offspring involving altered lxra DNA methylation. Cell Metab. 2014, 19, 941-951. [CrossRef] [PubMed]

80. Ng, S.F.; Lin, R.C.; Laybutt, D.R.; Barres, R.; Owens, J.A.; Morris, M.J. Chronic high-fat diet in fathers programs beta-cell dysfunction in female rat offspring. Nature 2010, 467, 963-966. [CrossRef] [PubMed]

81. McPherson, N.O.; Owens, J.A.; Fullston, T.; Lane, M. Preconception diet or exercise intervention in obese fathers normalizes sperm microrna profile and metabolic syndrome in female offspring. Am. J. Physiol. Endocrinol. Metab. 2015, 308, E805-E821. [CrossRef] [PubMed]

(C) 2016 by the authors; licensee MDPI, Basel, Switzerland. This article is an open access article distributed under the terms and conditions of the Creative Commons Attribution (CC-BY) license (http:/ / creativecommons.org/licenses/by/4.0/). 